\title{
Certified IRB Professional
}

National Cancer Institute

\section{Source}

National Cancer Institute. Certified IRB Professional. NCI Thesaurus. Code C142418.

An individual certified to administer and oversee the activities of an institutional review board. The individual must satisfy education and employment requirements and pass an examination conducted by the applied research ethics national association, which is the membership division of Public Responsibility in Medicine and Research. 